\title{
Potensi lokal Gunung Ijen untuk pemahaman konsep dan berpikir kreatif pengurangan resiko bencana
}

\author{
Khatriya Tiffani Tamimiya *, I Gusti Putu Suryadarma \\ Program Studi Pendidikan IPA, Program Pascasarjana, Universitas Negeri Yogyakarta. \\ Jalan Colombo No. 1, Karangmalang, Yogyakarta 55281, Indonesia. \\ * Coressponding Author. E-mail: khatriya.tiffani.tamimiya@gmail.com \\ Received: 25 June 2019; Revised:23 July 2019; Accepted: 7 August 2019
}

\begin{abstract}
Abstrak
Penelitian ini bertujuan untuk mengungkapkan: (1) kelayakan dan (2) efektifitas Lembar Kerja Peserta Didik (LKPD) IPA berbasis project-based learning (PjBL) terintegrasi potensi lokal Gunung Ijen dalam meningkatkan pemahaman konsep lapisan Bumi dan berpikir kreatif peserta didik. Penelitian ini mengacu pada model pengembangan 4D. Uji coba empiris dilakukan pada satu kelas eksperimen terdiri dari 28 siswa dan satu kelas kontrol terdiri dari 24 siswa. Hasil penelitian menunjukkan bahwa LKPD IPA berbasis PjBL terintegrasi potensi lokal Gunung Ijen layak digunakan sebagai bahan ajar dalam meningkatkan pemahaman konsep dan berpikir kreatif peserta didik dengan kategori sangat baik dengan skor sebesar 3,75 menurut validator ahli materi dan 3,68 menurut validator ahli media. LKPD IPA tersebut efektif meningkatkan pemahaman konsep dan berpikir kreatif dengan signifikansi sebesar 0,000 (sig< 0,05). Pemanfaatan produk dapat digunakan untuk sekolah-sekolah di sekitar kawasan Gunung Ijen. Sekolah yang jauh dari kawasan Gunung Ijen, dapat melakukan modifikasi tentang potensi lokal sesuai dengan daerah masing-masing.
\end{abstract}

Kata kunci: LKPD, PjBL, potensi lokal, pemahaman konsep, berpikir kreatif

\section{Mount Ijen's local potential to understanding concept and creative thinking of disaster risk reduction}

\begin{abstract}
This study aims to reveal: (1) the feasibility and (2) effectiveness of Project Based-Learning (PjBL)-based science student worksheet (LKPD) integrated to Mount Ijen's local potential in improving the students' understanding of Earth layer concept and creative thinking.This study refers to the the development model of $4 D$. The empirical trial was conducted to one experimental class consisting of 28 students and one control class consisting of 24 students. The results show that the developed PjBL-based science LKPD integrated to Mount Ijen's local potential is worthy of being used as teaching materials by improving the concepts and creative thinking of student understanding with a very good category with the final score of 3.75 according to the material expert validator and 3.68 according to the media expert validator. The developed science LKPD is significantly effective in improving students' understanding of concepts and creative thinking at the significance level of 0.000 (sig < 0.05 ). It can be used for schools around the area of Mount Ijen. For schools that are extremely far from Mount Ijen, the modifications can be made about the local potential according to their respective regions.
\end{abstract}

Keywords: concept understanding, creative thinking, $L K P D$, local potential, PjBL

How to Cite: Tamimiya, K., \& Suryadarma, I. (2019). Potensi lokal Gunung Ijen untuk pemahaman konsep dan berpikir kreatif pengurangan resiko bencana. Jurnal Inovasi Pendidikan IPA, 5(1), 111-128. doi:https://doi.org/10.21831/jipi.v5i1.25702

do https://doi.org/10.21831/jipi.v5i1.25702

\section{PENDAHULUAN}

Sumber daya alam dan sumber daya manusia merupakan potensi yang harus dikembangkan secara optimal demi kemajuan bangsa dalam menghadapi perkembangan zaman. Sumber daya alam dan manusia yang melimpah merupakan aset besar bangsa Indonesia yang dapat diolah sebagai modal menjadi negara maju. Indonesia merupakan negara berkembang yang memiliki potensi untuk menjadi negara maju karena sumber daya manusia yang melimpah. Menurut survei yang dilakukan SUPAS (Badan 
Pusat Statistik, 2018) pada tahun 2020-2030 Indonesia memiliki peluang munculnya bonus demografi, yaitu peluang yang dinikmati suatu negara karena besarnya proporsi penduduk produktif (15-64 tahun) dibandingkan penduduk usia nonproduktif (usia kurang dari 15 tahun dan lebih dari 65 tahun).

Peluang munculnya bonus demografi di Indonesia harus dipersiapkan dengan baik agar dapat memberi dampak positif bagi kemajuan bangsa dalam jangka panjang. Hal ini sejalan dengan paparan Wakil Menteri Bidang Pendidikan dan Kebudayaan Republik Indonesia (2004) yang mengungkapkan bahwa bonus demografi merupakan modal pembangunan negara yang harus dioptimalkan. Optimalisasi yang dirasa paling penting adalah melakukan transformasi pada bidang pendidikan. Sani (2014) mengungkapkan tentang hasil berbagai penelitian yang menunjukkan bahwa investasi dalam bidang pendidikan menghasilkan manfaat yang jauh lebih besar daripada investasi dalam bidang ekonomi. Beberapa negara yang bersungguh-sungguh mengembangkan sumberdaya manusia melalui pendidikan ternyata berhasil mengembangkan sains, teknologi, dan ekonomi dengan cepat sehingga saat ini menjadi negara maju seperti Jepang dan Korea Selatan.

Sumber daya manusia yang dihasilkan diharapkan mampu mengolah dengan baik sumberdaya alam Indonesia. Sehingga Indonesia dapat menjadi negara maju yang mandiri tanpa tergantung dengan negara asing dalam mengolah kekayaan alam. Sumber daya manusia yang unggul dapat dilahirkan dari sistem pendidikan yang baik yang didukung dari berbagai aspek seperti lingkungan sekolah, guru yang kompeten, peserta didik yang memiliki kesadaran belajar, dan sarana prasarana yang mendukung. Berdasarkan penelitian pendahuluan yang peneliti lakukan, kenyataan di lapangan menunjukkan kurang optimalnya aspek pendukung keberhasilan pendidikan di sebagian daerah. Menurut hasil wawancara peneliti dengan guru IPA, peserta didik di SMP Negeri 1 Tamanan kurang memiliki kesadaran dalam belajar yang dapat dilihat dari sikap mereaka dalam pembelajaran dan hasil belajar yang kurang memuaskan. Menurut guru di sekolah, hal tersebut dapat disebabkan oleh beberapa hal seperti lingkungan keluarga yang kurang mampu, kesadaran untuk belajar dalam masyarakat yang masih rendah, serta sarana dan prasarana yang kurang mendukung. Keadaan tersebut harus diatasi dengan inovasi-inovasi yang dilakukan oleh guru yang berperan sebagai penggerak pembelajaran.

Salah satu inovasi yang dapat dilakukan guru adalah membuat bahan ajar yang dapat meningkatkan motivasi peserta didik seperti menghadirkan kehidupan nyata atau sesuatu yang ada di lingkungan ke dalam pembelajaran. Kekayaan atau potensi lokal daerah dapat dijadikan tema dalam mengembangkan bahan ajar adalah potensi lokal yang ada di sekitar peserta didik. Seperti yang diungkapkan oleh Juniati \& Sari (2016) bahwa potensi lokal merupakan pembelajaran nyata yang mampu melayani masyarakat dalam memecahkan masalah lingkungan. Bahan ajar yang dikembangkan dengan tema potensi lokal dapat dilakukan dengan berbagai cara, salah satunya yaitu merancang pembelajaran berdasarkan potensi lokal sebagai sumber belajar yang dikemas dalam bentuk lembar kerja peserta didik (LKPD). Menurut Prastowo (2011) lembar kerja peserta didik disusun dengan tujuan menyajikan bahan ajar yang memudahkaan peserta didik berinteraksi dengan materi yang sedang diajarkan.

Sumber daya alam dapat ditemukan di berbagai daerah di Indonesia seperti Gunung Ijen yang terdapat di Jawa Timur. Gunung Ijen memiliki karakteristik dan keunggulan yang unik dan berbeda dengan daerah lain di Indonesia seperi kenampakan lapisan Bumi, kawah yang menghasilkan belerang terbesar ke-2 terbesar di dunia, blue fire yang dapat dilihat pada malam hari, dan potensi di bidang perkebunan. Keunggulan daerah yang berbeda dengan daerah lainnya bisa kita sebut dengan potensi lokal. Di samping potensi yang luar biasa, Gunung Ijen juga berpotensi menghadirkan fenomena alam seperti gunung meletus dan gempa Bumi. Gunung meletus dan gmpa Bumi merupakan fenomena alam yang suatu saat pasti terjadi di sekitar gunung berapi. Oleh sebab itu diperlukan pembelajaran tentang pengurangan resiko bencana yang harus dimiliki oleh peserta didik sedini mungkin. Indonesia merupakan negara dengan potensi bencana alam sangat tinggi khususnya gempa bumi, letusan gunung berapi, dan Tsunami karena terletak pada pertemuan tiga lempeng/kerak bumi aktif. Edukasi bencana sangat diperlukan sebagai pembelajaran agar para peserta didik selalu siap dalam menghadapi bencana dan mengetahui tindakan yang harus dilakukan saat evakuasi terjadi (Rosita, 2015).

Potensi lokal dan dampaknya tersebut dapat dimanfaatkan oleh guru sebagai sumber belajar. Pemanfaatan potensi lokal sebagai sum- 
ber belajar sangat cocok dikembangkan dalam pembelajaran seperti himbauan pemerintah dalam pada pasal 36 ayat (2) Undang-undang Nomor 20 Tahun 2003 tentang Sistem Pendidikan Nasional yang berbunyi "Kurikulum pada semua jenjang dan jenis pendidikan dikembangkan dengan prinsip diversivikasi sesuai dengan satuan pendidikan, potensi daerah, dan peserta didik" (Presiden Republik Indonesia, 2003). Sya`ban \& Wilujeng (2016) berpendapat bahwa potensi lokal merupakan kekhasan suatu tempat sebagai salah satu identitas atau ciri suatu daerah yang bernilai lebih dibandingkan dengan daerah yang lain, meliputi aspek ekologi yang dikembangkan dari sumber daya alam untuk mengajarkan masyarakat setempat untuk menjaga dan melestarikan lingkungannya. Pembelajaran dengan potensi lokal diharapkan mampu membentuk peserta didik yang siap menghadapi masa depan dengan memanfaatkan potensi lokal yang ada di daerah. Wilujeng, Prasetyo, \& Suryadarma (2017) berpendapat bahwa potensi lokal yang ada di Indonesia dapat digunakan dalam usaha memajukan bangsa sebagai pertimbangan merencakan pembelajaran di sekolah.

Sebagai studi pendahuluan, peneliti melakukan survei melalui google form mengenai keterlaksanaan pembelajaran IPA pada materi lapisan Bumi dan dinamikanya pada sebagian wilayah Jawa Timur khususnya daerah yang dekat dengan Gunung Ijen. Hasil yang diperoleh menunjukkan bahwa $100 \%$ guru yang mengisi angket setuju pembelajaran terintegrasi dengan potensi lokal, tetapi sebesar yaitu $66,7 \%$ belum memasukkan Gunung Ijen sebagai topik dalam materi lapisan Bumi dan dinamikanya, 27,8\% guru yang mengisi angket pernah mengembangkan LKPD terintegrasi potensi lokal dan sisanya belum pernah yaitu sebesar $72,22 \%$. Kendala terbesar yang diungkapkan oleh peserta survei adalah kurangnya pelatihan mengenai pengembangan bahan ajar berbasis potensi lokal, membutuhkan waktu dan tenaga yang lebih, dan kurangnya pemahaman mengenai potensi lokal.

Tujuan dari semua strategi dan inovasi yang dikembangkan oleh para guru agar para peserta didik mendapat pengetahuan yang utuh. Peserta didik diharapkan memiliki berbagai macam kompetensi baik dalam pengetauan (kognitif), keterampilan (psikomotor), maupun sikap dan perilaku (afektif). (Kementerian Pendidikan dan Kebudayaan Republik Indonesia, 2013) menggambarkan skema kompetensi yang harus diterapkan dalam pembelajaran seperti Gambar 1.

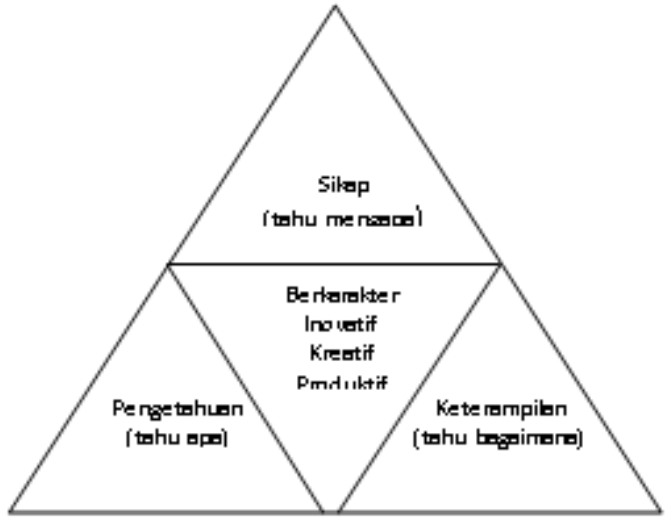

Gambar 1. Skema Kompetensi yang Harus

Diterapkan dalam Pembelajaran

Skema pada Gambar 1, menggambarkan bahwa peserta didik diharapkan menguasai seluruh kompetensi secara utuh dan menyeluruh agar memiliki karakter yang baik, inovatif, kreatif, dan produktif. Salah satu tujuan pembelajaran yang wajib di kuasai peserta didik adalah pemahaman konsep dari materi yang sedang dipelajari. Hasil belajar dikatakan baik jika peserta didik mampu memahami konsep utama dalam suatu subjek dan tidak hanya sekedar mengingat fakta yang terpisah-pisah. Pemahaman konsep akan berkembang apabila guru dapat membantu peserta didik mengeksplorasi topik secara mendalam dan memberi mereka contoh yang tepat dan sesuai dengan kehidupan sehari-hari agar konsep yang dipelajarai dapat dipahami dengan baik.

Eksplorasi topik pembelajaran yang mengangkat kehidupan sehari-hari dapat dioptimalkan dengan suatu model pembelajaran project-based learning. Menurut Wiek, Xiong, Brundiers, \& van der Leeuw (2014) projectbased learning mendorong peserta didik secara aktif, mandiri, dan bertanggung jawab mengembangkan pengetahuan, keterampilan, dan sikap, jika didukung dengan memperdalam pengalaman dan strategi pembelajaran. Sani (2014) mengungkapkan bahwa project-based learning merupakan pembelajaran yang melibatkan peserta didik untuk mengerjakan suatu proyek yang dipandang mampu memberikan manfaat dalam menyelesaikan masalah yang terjadi di masyarakat dan lingkungan disekitar tempat tinggal peserta didik. Dengan model pembelajaran berbasis proyek, peserta didik diharapkan mampu memahami konsep yang sedang dikaji karena berhubungan langsung dengan masalah yang terjadi di lingkungan tempat tinggal peserta didik. Project-based learning juga berdampak 
baik pada kreativitas peserta didik yang sangat diperlukan pada saat ini dan di masa depan.

Perkembangan zaman menuntut masyarakat memiliki kreativitas dalam berbagai bidang agar mampu bertahan di era global. Kreativitas memiliki beberapa komponen yaitu ketermpilan berpikir kreatif, keahlian, dan motivasi. Keterampilan berpikir kreatif dapat dilihat dari pengajuan ide yang berbeda dalam mendapatkan suatu solusi. Keterampilan berpikir kreatif setiap peserta didik berbeda-beda sesuai dengan pengetahuan awal yang dimiliki peserta didik. (Sudarma, 2013) berpendapat bahwa keterampilan berpikir yang dimiliki seseorang akan menjadi modal dalam memecahkan masalah yang terjadi dalam kehidupan. Sebagai lembaga yang menyiapkan sumber daya manusia, sekolah khususnya guru hendaknya mampu membantu peserta didik mengeksplor kreativitas dalam pembelajaran agar mampu mengaplikasikan ilmu yang telah didapat di sekolah ke dalam kehidupan sehari-hari baik dalam lingkungan keluarga maupun lingkungan masyarakat.

Melalui topik lapisan Bumi dan dinamikanya dalam potensi lokal Gunung Ijen, peserta didik dilatih untuk mengasah kreatifitas terutama dalam berpikir kreatif dalam usaha penguangan resiko bencana yang rawan terjadi di kawasan Gunung Ijen. Sesuai dengan pendapat (Sudarma, 2013), penggunaan topik yang dekat dangan keseharian peserta didik dapat mengasah kemampuan berpikir kreatif dalam mengatasi permasalahan lingkungan yaitu dampak dari bencana alam yang mungkin terjadi di kawasan tersebut.

Berdasarkan pemaparan tersebut, peneliti tertarik untuk mengembangkan LKPD IPA berbasis potensi lokal Gunung Ijen untuk meningkatkan pemahaman konsep lapisan bumi dan keterampilan berpikir kreatif dalam pengurangan resiko bencana.

\section{METODE}

Penelitian ini termasuk jenis penelitian dan pengembangan yang dikenal Research and Development $(R \& D)$ dengan mengadaptasi model pengembangan 4D Thiagarajan. Model pengembangan 4D terdiri dari 4 tahapan, yaitu: tahap Define (pendefinisian), Design (perencanaan), Develop (pengembangan), dan Disseminate (penyebaran). Desain yang digunakan dalam uji coba lapangan adalah desain pretest-posttest control group design.

Penelitian dilakukan pada bulan Maret 2019 di SMP Negeri 1 Tamanan, Kabupaten Bondowoso, Provinsi Jawa Timur. Subjek
Penelitian pada penelitian ini adalah peserta didik kelas VII SMP Negeri 1 Tamanan. Penelitian dilakukan dengan mengambil dua kelas uji coba. Kedua kelas tersebut digunakan sebagai kelas kontrol dan eksperimen, penentuan kelas kontrol dan eksperimen dilakukan secara acak dengan syarat kelas tersebut homogen. Untuk mengetahui sifat homogen dilakukan uji homogenitas antara bebera pakelas VII yang ada. Hasil validasi yang dilakukan oleh validator ahli materi dan ahli media, dan praktisi (guru IPA) diperoleh dengan Persamaan 1.

$\bar{x}=\frac{\sum x}{n}$

Berdasarkan Persamaan 1, $\bar{x}$ merupakan rata-rata skor, $\sum x$ adalah jumlah skor tiap komponen, dan $n=$ jumlah validator/praktisi/ peserta didik. Hasil rata-rata yang diperoleh dari perhitungan menggunakan persamaan (1) akan dikonversi menjadi kategori berdasarkan Tabel 1.

Tabel 1. Pedoman Penskoran Hasil Validasi Produk

\begin{tabular}{llll}
\hline No. & Rentang Skor & Nilai & Kategori \\
\hline 1. & $\mathrm{X}>\bar{X}+1 . \mathrm{SBx}$ & $\mathrm{A}$ & SangatBaik \\
2. & $\bar{X}+1 . \mathrm{SBx}>\mathrm{X} \geq \bar{X}$ & $\mathrm{~B}$ & Baik \\
3. & $\bar{X}>\mathrm{X} \geq \bar{X}+1 . \mathrm{SBx}$ & $\mathrm{C}$ & Cukup \\
4. & $\mathrm{X}<\bar{X}+1 . \mathrm{SBx}$ & $\mathrm{D}$ & Kurang \\
\hline
\end{tabular}

(Mardapi, 2008)

Berdasarkan Tabel 1, $\bar{X}$ adalah rerata skor ideal $(1 / 2$ (skor tertinggi ideal + skor terendah ideal)). $\mathrm{X}$ adalah skor rata-rata yang diperoleh. SBx yaitu simpangan baku skor ideal ((1/2) (1/3) (skor tertinggi ideal + skor terendah ideal)). Untuk menghitung skor tertinggi ideal dihitung dari $\Sigma$ butir kriteria $\mathrm{x}$ skor tertinggi. Sedangkan skor terendah ideal dihitung dari $\Sigma$ butir kriteria $\mathrm{x}$ skor terendah.

Data pemahaman konsep dan berpikir kreatif dalam pengurangan resiko bencana diperoleh melalui hasil pretest dan posttest peserta didik pada kelas eksperimen dan kelas kontrol. Nilai yang diperoleh selanjutnya diolah dan dianalisis dengan $\mathrm{n}$ gain score ternormalisasi untuk melihat peningkatan pemahaman konsep dan berpikir kreatif dalam pengurangan resiko bencana. Rumus yang digunakan untuk menghitung gain score ternormalisasi ( $g$ ) menurut (Hake, 1999) seperti Persamaan 2.

$(g)=\frac{T_{2}-T_{1}}{I_{S}-T_{1}}$ 
Berdasarkan Persamaan 2, $\mathrm{T}_{1}$ merupakan nilai pretest. $\mathrm{T}_{2}$ merupakan nilai posttest. Sedangkan I $I_{S}$ adalah Skor maksimal pretest atau posttest. Perolehan gain ternormalisasi untuk masingmasing peserta didik dihitung rata-ratanya. Nilai gain rata-rata kemudian dikategorikan menurut (Hake, 1999). Kategorisasi perolehan gain siswa disajikan pada Tabel 2.

Tabel 2.Kategorisasi Perolehan Gain Skor Siswa

\begin{tabular}{ll}
\hline Interval & Kategori \\
\hline$(\mathrm{g}) \geq 0,7$ & Tinggi \\
$0,7>(\mathrm{g}) \geq 0,3$ & Sedang \\
$(\mathrm{g})<0,3$ & Rendah \\
\hline
\end{tabular}

Uji Manova bertujuan untuk melihat adanya perbedaan posttest antara kedua kelompok sampel dengan dua variabel yaitu pemahaman konsep dan berpikir kreatif dalam pengurangan resiko bencana. Analisis dilakukan dengan menggunakan SPSS 16 for windows pada taraf signifikansi $(\alpha)$ 0,05. Hipotesis yang diajukan dalam uji Manova sebagai berikut: Pertama, $\mathrm{H}_{\mathrm{o}}$ berarti tidak ada pengaruh yang signifikan penggunaan LKPD IPA berbasis PjBL terintegrasi potensi lokal Gunung Ijen terhadap peningkatan pemahaman konsep dan berpikir kreatif dalam pengurangan resiko bencana peserta didik. Kedua, $\mathrm{H}_{1}$ berarti ada pengaruh yang signifikan penggunaan LKPD IPA berbasis PjBL terintegrasi potensi lokal Gunung Ijen terhadap peningkatan pemahaman konsep dan berpikir kreatif dalam pengurangan resiko bencana peserta didik.

\section{HASIL DAN PEMBAHASAN}

\section{Hasil}

\section{Kelayakan LKPD oleh Validator Ahli}

Kelayakan merupakan syarat mutlak yang harus dimiliki suatu bahan ajar agar dapat digunakan dalam pembelajaran. Pada penelitian ini kelayakan LKPD IPA divalidasi oleh dua validator ahli yaitu ahli materi dan ahli media. Tujuan dari proses validasi adalah untuk menilai kelayakan produk LKPD IPA yang dikembangkan serta untuk mendapat kritik dan saran yang dapat menyempurnakan LKPD.

Produk LKPD IPA dinilai/divalidasi oleh dua validator ahli yaitu validator ahli materi dan ahli media. Penilaian dari validator ahli dilakukan dengan menggunakan pedoman lembar validasi ahli materi dan ahli media. Hasil dari penilaian akan digunakan sebagai tolok ukur kelayakan LKPD IPA sesuai keriteria yang telah ditetapkan. Penilaian dari validasi menghasilkan kritik dan saran yang digunakan sebagai bahan perbaikan dan penyempurnaan produk LKPD IPA yang dikembangkan.

Penilaian kelayakan LKPD IPA pada lembar kelayakan menggunakan skala empat dalam setiap aspek. Perolehan skor dari kelayakan LKPD IPA kemudian dikonversikan menjadi kategori seperti pada Tabel 3.

Tabel 3. Konversi Skor Kelayakan menjadi Kategori

\begin{tabular}{llll}
\hline No. & Rentang Skor & Nilai & Kategori \\
\hline 1. & $\mathrm{X}>2,67$ & A & Sangat Baik \\
2. & $2,67>\mathrm{X} \geq 2$ & $\mathrm{~B}$ & Baik \\
3. & $2>\mathrm{X} \geq 2,67$ & $\mathrm{C}$ & Cukup \\
4. & $\mathrm{X}<2,67$ & $\mathrm{D}$ & Kurang \\
\hline
\end{tabular}

Tabel konversi pada Tabel 3 dapat dijadikan pedoman untuk mengkategorikan hasil penilaian dari validator ahli dan guru IPA. Hasil penilaian kelayakan LKPD menurut validator ahli materi dengan perolehan skor rata-rata sebesar 3,75 dalam kategori sangat baik seperti pada Tabel 4.

Tabel 4. Hasil Analisis Kelayakan LKPD oleh Validator Ahli Materi

\begin{tabular}{lllll}
\hline No. & $\begin{array}{c}\text { Aspek } \\
\text { Kelayakan }\end{array}$ & Skor & $\begin{array}{c}\text { Skor } \\
\text { Rata- } \\
\text { rata }\end{array}$ & $\begin{array}{c}\text { Kategori } \\
\text { LKPD }\end{array}$ \\
\hline 1. & Kelayakan Isi & 3,5 & 3,75 & Sangat \\
2. & Kebahasaan & 4 & & Baik \\
3. & Penyajian & 4 & & \\
4. & Karakteristik & 3,5 & & \\
\hline
\end{tabular}

Hasil penilaian kelayakan LKPD menurut validator ahli media terdapat dalam Tabel 5.

Tabel 5. Hasil Analisis Kelayakan LKPD oleh Validator Ahli Media

\begin{tabular}{lllll}
\hline No. & $\begin{array}{c}\text { Aspek } \\
\text { Kelayakan }\end{array}$ & Skor & $\begin{array}{c}\text { Skor } \\
\text { rata- } \\
\text { rata }\end{array}$ & $\begin{array}{c}\text { Kategori } \\
\text { LKPD }\end{array}$ \\
\hline 1. & $\begin{array}{l}\text { Format } \\
\text { LKPD }\end{array}$ & 3,86 & 3,68 & $\begin{array}{l}\text { Sangat } \\
\text { Baik }\end{array}$ \\
2. & Kegrafikaan & 3,5 & & \\
\hline
\end{tabular}

Berdasarkan Tabel 5, dapat diketahui bahwa produk LKPD IPA yang dikembangkan layak menurut validator ahli media dengan perolehan skor rata-rata 3,68 dalam kategori sangat baik.

\section{Kepraktisan LKPD oleh Guru IPA}

Kepraktisan dinilai oleh guru IPA untuk mengetahui praktis atau tidaknya LKPD IPA yang telah dikembangkan. Pada penelitian ini kepraktisan LKPD dinilai oleh tiga guru IPA. Penilaian, kritik, dan saran dari praktisi akan 
digunakan sebagai bahan evaluasi dan penyempurnaan LKPD IPA yang dikembangkan. Hasil penilaian kepraktisan LKPD dapat dilihat pada Tabel 6.

Tabel 6. Hasil Kepraktisan LKPD oleh Guru IPA

\begin{tabular}{lllcc}
\hline No. & $\begin{array}{c}\text { Aspek } \\
\text { Kelayakan }\end{array}$ & Skor & $\begin{array}{c}\text { Rata- } \\
\text { rata } \\
\text { Skor }\end{array}$ & $\begin{array}{c}\text { Kategori } \\
\text { LKPD }\end{array}$ \\
\hline 1. & Kelayakan Isi & 3,89 & 3,84 & Sangat \\
2. & Kebahasaan & 4 & & Baik \\
3. & Penyajian & 3,83 & & \\
4. & Keterlaksanaan & 3,67 & & \\
\hline
\end{tabular}

Berdasarkan Tabel 6, dapat diketahui bahwa produk LKPD IPA yang dikembangkan praktis digunakan menurut guru IPA dengan perolehan skor rata-rata 3,84 dalam kategori sangat baik.

\section{Uji Coba Terbatas}

Uji coba terbatas dilakukan untuk mengetahui keterbacaan LKPD IPA yang telah dikembangkan. Uji coba terbatas dilakukan terhadap 15 peserta didik di SMP Negeri 1 Tamanan. Peserta didik yang mengisi lembar keterbacaan LKPD adalah peserta didik yang memiliki kemampuan yang berbeda yaitu 5 peserta didik dengan kategori rendah, 5 peserta didik dengan kategori sedang, dan 5 orang dengan tinggi. Pengelompokan tersebut didapa dari nilai ulangan semester sebelumnya yang diberikan oleh guru IPA. Respon peserta didik tentang keterbacaan LKPD IPA berbasis project-based learning terintegrasi potensi lokal Gunung Ijen memiliki kategori yang sangat baik. Hal ini dapat dilihat dari perolehan skor rata-rata yang diperoleh dari pengolahan data respon keterbacaan peserta didik yang mencapai $88 \%$.

\section{Uji Coba Lapangan}

Uji coba lapangan dilakukan untuk mengetahui keefektifan produk LKPD IPA yang telah dikembangkan. Uji coba lapangan dilakukan di SMP Negeri 1 Tamanan yang terletak di kabupaten Bondowoso, Jawa Timur. Alasan peneliti melakukan penelitian di sekolah tersebut karena lokasi yang cukup dekat dengan Gunung Ijen. Penelitian dilakukan terhadap dua kelas yaitu kelas VII A dengan 28 pesera didik sebagai kelas eksperimen dan kelas VII B dengan 24 peserta didik sebagai kelas kontrol. LKPD yang diujikan dalam uji coba lapangan adalah draft 3 yang telah direvisi sesuai dengan dengan kritik dan saran dari validator ahli dan guru IPA. Uji lapangan menghasilkan data yang digunakan untuk menganalisis keefektifan LKPD IPA berbasis PjBL terintegrasi potensi lokal Gunung Ijen terhadap peningkatan pemahaman konsep dan berpikir kreatif peserta didik. Hasil uji lapangan dalam penelitian ini terdiri dari beberapabagian sebagai berikut.

Keefektifan Produk terhadap Peningkatan Pemahaman Konsep dan Berpikir Kreatif

Keefektifan produk LKPD IPA diperoleh dari uji MANOVA yang merupakan uji beda antara kelas eksperimen dan kelas kontrol dengan dua vaiabel yaitu pemahaman konsep dan berpikir kreatif peserta didik. Nilai yang diperoleh dari kelas kontrol dan kelas eksperimen dianalisis kenaikannya pada setiap aspek dalam setiap variabel. Setelah dilakukan pengolahan data, hal selanjutnya adalah melakukan uji prasyarat terlebih dahulu dengan uji normalitas dan homogenitas. Hasil dari pengolahan data dan uji yang dilakukan dalam penelitian ini sebagai berikut.

Analisis Peningkatan Pemahaman Konsep Lapisan Bumi

Pemahaman konsep lapisan Bumi merupakan salah satu variabel dalam penelitian ini. Pengukuran dilakukan dengan membandingkan rata-rata $n$-gain pemahaman konsep kelas kontrol dan kelas eksperimen seperti yang disajikan dalam Tabel 7.

Tabel 7. Rata-rata $n$ gain Pemahaman Konsep Kelas Eksperimen dan Kontrol

\begin{tabular}{llll}
\hline \multirow{2}{*}{ Kelas } & \multicolumn{2}{c}{ Pemahaman Konsep } & \multirow{2}{*}{ n gain } \\
\cline { 2 - 3 } & \multicolumn{1}{c}{ Pretest } & Posttest & \\
\hline Eksperimen & 24,5 & 76,50 & 0,69 \\
Kontrol & 33,17 & 64,13 & 0,46 \\
\hline
\end{tabular}

Berdasarkan Tabel 7, diketahui bahwa kenaikan nilai pemahaman konsep kelas eksperimen lebih tinggi dari pada kelas kontrol. Nilai n gain yang diperoleh kelas eksperimen sebesar 0,69 dengan kategori sedang dan 0,46 untuk kelas kontrol juga dengan kategori sedang. Untuk mempermudah melihat perbedaan $\mathrm{n}$ gain yang diperoleh kedua kelas, maka data yang diperoleh disajikan pada Gambar 1.

Pemahaman konsep yang diukur dalam penelitian ini menggunakan lima aspek yang diujikan, yaitu aspek menafsirkan, mencontohkaan, mengklasifikasi, merangkum, dan menyimpulkan. Setiap aspek memiliki pencapaian skor yang berbeda-beda seperti terlihat dalam Tabel 8 dan Gambar 2. 


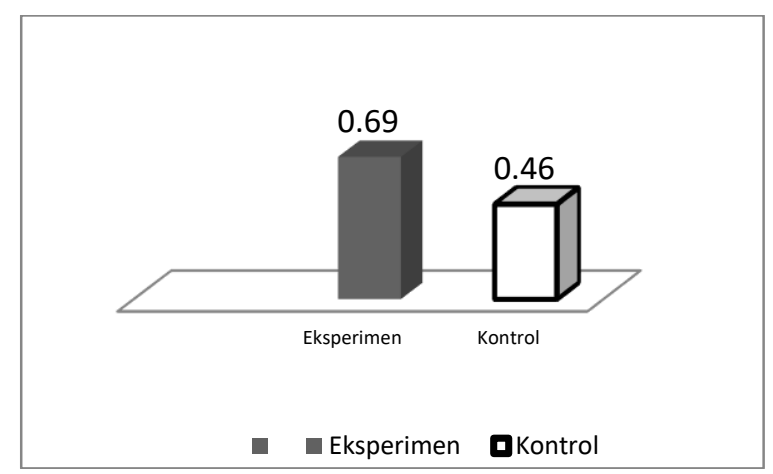

Gambar 1. Grafik Perbandingan n gain Kelas Eksperimen dan Kontrol

Tabel 8. Nilai Gain Pemahaman Konsep dalam Setiap Aspek

\begin{tabular}{lll}
\hline \multicolumn{1}{c}{ Aspek } & \multicolumn{1}{c}{ n gain } \\
Eksperimen & \multicolumn{1}{c}{$\begin{array}{c}\text { K gain } \\
\text { Kontrol }\end{array}$} \\
\hline Menafsirkan & 0,79 & 0,44 \\
Mencontohkan & 0,83 & 0,74 \\
Mengklasifikasi & 0,74 & 0,61 \\
Merangkum & 0,15 & 0,13 \\
Menyimpulkan & 0,79 & 0,34 \\
\hline
\end{tabular}

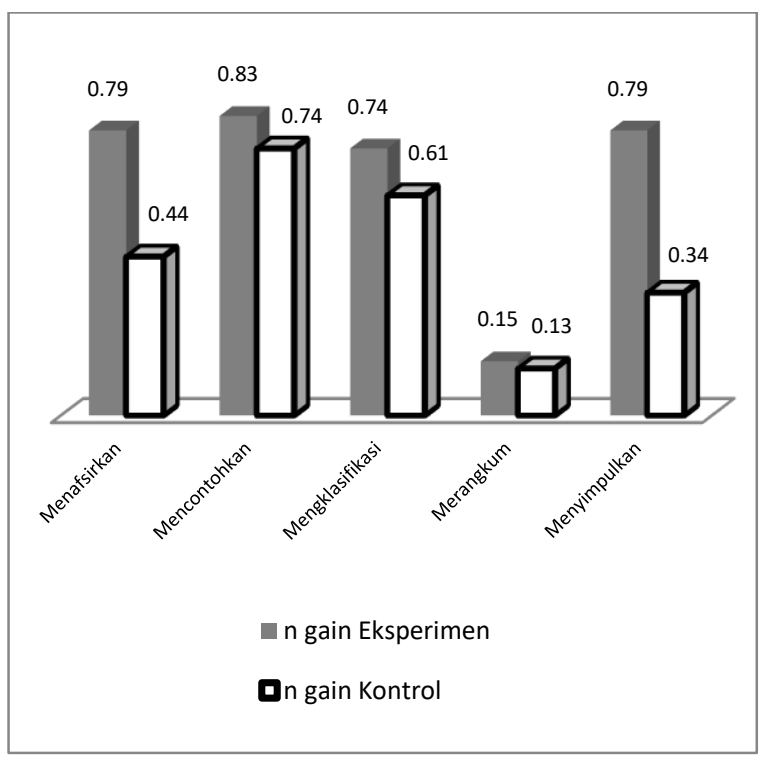

Gambar 2. Grafik Perbandingan n gain Aspek Pemahaman Konsep Kelas Eksperimen dan

\section{Kontrol}

Berdasarkan Gambar 2 diketahui bahwa terdapat perbedaan rata-rata $\mathrm{n}$ gain antara kelas eksperimen dan kelas kontrol di setiap aspek. Pada kelas eksperimen terdapat empat aspek dengan kategori tinggi dan satu aspek dalam kategori rendah yaitu aspek merangkum. Sedangkan pada kelas kontrol terdapat macam-macam kategori dari kategori rendah hingga tinggi seperti pada Tabel 8 dan Gambar 2.

\section{Analisis Peningkatan Berpikir Kreatif}

Berpikir kreatif merupakan salah satu variabel dalam penelitian ini. Pengukuran dilakukan dengan membandingkan rata-rata $\mathrm{n}$ gain berpikir kreatif kelas kontrol dan kelas eksperimen seperti yang disajikan dalam Tabel 9.

Tabel 1. Rata-rata $\mathrm{n}$ gain Berpikir Kreatif Kelas Esperimen dan Kontrol

\begin{tabular}{llll}
\hline \multirow{2}{*}{ Kelas } & \multicolumn{2}{c}{ Berpikir Kreatif } & \multirow{2}{*}{ n gain } \\
\cline { 2 - 3 } & Pretest & Posttest & \\
\hline Eksperimen & 14,11 & 75,82 & 0,72 \\
Kontrol & 15,21 & 56,25 & 0,48 \\
\hline
\end{tabular}

Berdasarkan Tabel 9, diketahui bahwa kenaikan nilai berpikir kreatif dalam pengurangan resiko bencana kelas eksperimen lebih tinggi dari pada kelas kontrol. Nilai $n$ gain yang diperoleh kelas eksperimen sebesar 0,72 dengan kategori tinggi dan 0,48 untuk kelas kontrol juga dengan kategori sedang. Untuk mempermudah melihat perbedaan $n$ gain yang diperoleh kedua kelas, disajikan Gambar 3.

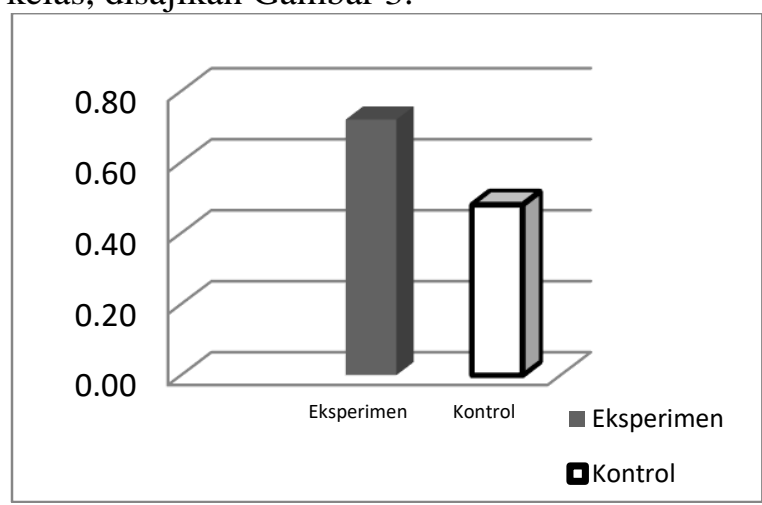

Gambar 3. Grafik Perbandingan n gain Berpikir

Kreatif Kelas Eksperimen dan Kontrol

Variabel berpikir kreatif dalam pengurangan resiko bencana yang diukur dalam penelitian ini menggunakan tiga aspek yang diujikan, yaitu aspek kelancaran, fleksibel, dan elaborasi. Setiap aspek memiliki pencapaian skor yang berbedabeda seperti terlihat dalam Tabel 10 dan Gambar 4.

Tabel10. Nilai Gain Berpikir Kreatif dalam Setiap Aspek

\begin{tabular}{lll}
\hline \multicolumn{1}{c}{ Aspek } & n gain Eksperimen & n gain Kontrol \\
\hline Kelancaran & 0,69 & 0,48 \\
Fleksibel & 0,72 & 0,5 \\
Elaborasi & 0,75 & 0,48 \\
& & \\
\hline
\end{tabular}




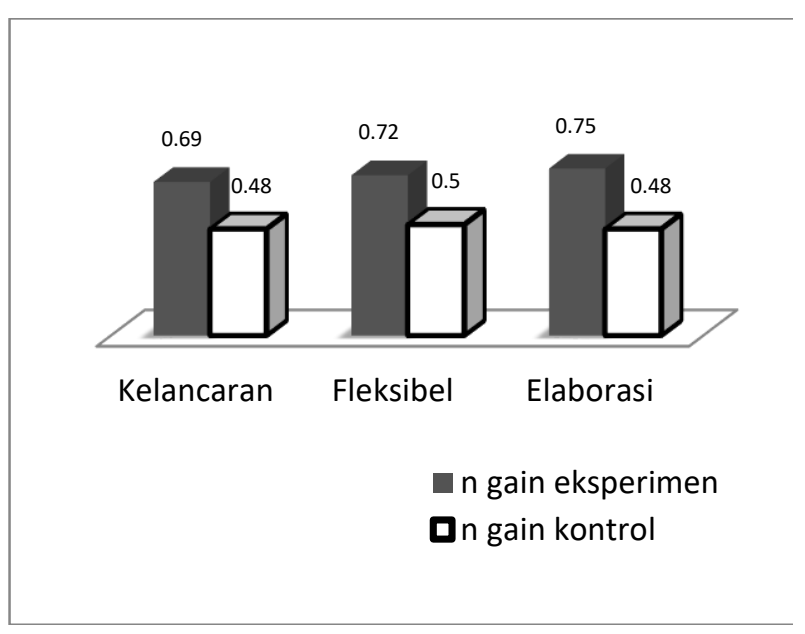

Gambar 4. Grafik Perbandingan n gain Aspek Berpikir Kreatif Kelas Eksperimen dan Kontrol

Berdasarkan Gambar 4 diketahui bahwa terdapat perbedaan rata-rata $\mathrm{n}$ gain antara kelas eksperimen dan kelas kontrol di setiap aspek. Pada kelas eksperimen aspek kelancaran memiliki n-gain sebesar 0,69 sehingga berkategori sedang, aspek fleksibel mimiliki $\mathrm{n}$ gain sebesar 0,72 dengan kategori tinggi, dan aspek elaborasi memiliki n-gain sebesar 0,75 dengan kategori tinggi. Sedangkan pada kelas kontrol, ketiga aspek berada dalam kategori sedang dengan perolehan $\mathrm{n}$ gain secara berturut-turut sebesar 0,$48 ; 0,5$; dan 0,48 .

\section{Uji MANOVA}

Uji MANOVA dilakukan setelah data hasil penelitian berupa data pemahaman konsep dan berpikir kreatif dinyatakan normal dan homogen. Hipotesis pada uji MANOVA adalah:Pertama, $\mathrm{H}_{\mathrm{o}}$ berarti tidak ada pengaruh yang signifikan penggunanaan LKPD IPA berbasis PjBL terintegrasi potensi lokal Gunung Ijen terhadap pemahaman konsep dan berpikir kreatif peserta didik.Kedua, $\mathrm{H}_{1}$ berarti Ada pengaruh yang signifikan penggunanaan LKPD IPA berbasis PjBL terintegrasi potensi lokal Gunung Ijen terhadap pemahaman konsep dan berpikir kreatif peserta didik.

Pengambilan keputusan hipotesis pada uji MANOVA dalam penelitian ini dapat dilihat dari nilai signifikansi yang diperoleh dalam uji MANOVA. Hasil analisa data dengan uji MANOVA disajikan dalam tabel berikut. Nilai signifikansi dari uji MANOVA sebesar 0.000. Hal tersebut menyatakan bahwa signifikansi lebih kecil dari pada alfa yaitu sebesar 0.05 (sig $<0.05$ ) sehingga $\mathrm{H}_{\mathrm{o}}$ ditolak dan $\mathrm{H}_{1}$ diterima. Berdasarkan hasil yang diperoleh dapat disimpulkan bahwa terdapat perbedaan yang signifikan antara rata-rata nilai pemahaman konsep dan berpikir kreatif peserta didik pada kelas kontrol dan kelas eksperimen. Terdapat perbedaan yang signifikan antara rata-rata nilai pemahaman konsep dan berpikir kreatif peserta didik pada kelas yang menggunakan LKPD IPA berbasis $\mathrm{PjBL}$ terintegrasi potensi lokal Gunung Ijen dengan kelas yang menggunakan buku ajar yang disediakan di sekolah.

\section{Pembahasan}

Lembar kerja peserta didik (LKPD) IPA yang dikembangkan merupakan LKPD berbasis PjBL terintegrasi potensial lokal Gunung Ijen. LKPD yang dikembangkan menggunakan sintak model PjBL yang terdiri dari penyajian permasalahan, membuat perencanaan, menyusun penjadwalan, memonitor pembuatan proyek, penilaian, dan evaluasi. Tujuan dari pengembangan LKPD IPA ini adalah untuk meningkatkan pemahaman konsep dan berpikir kreatif. Menurut (Mihardi, Harahap, \& Sani, 2010)penggunaan PjBL dapat meningkatkan berpikir kreatif peserta didik dengan memecahkan permasalahan dengan cara menghasilkan karya.

Isi LKPD IPA yang dikembangkan disesuaikan dengan KD 3.10 mengenai lapisan bumi dan dinamikanya. Materi dalam LKPD diintegrasikan dengan potensi lokal Gunung Ijen. Setiap permasalah yang disajian dipilih dari fenomena atau kejadian yang terjadi di sekitar Gunung Ijen. Penggunaan model PjBL dalam LKPD membantu menggiring peserta didik memecahkan permasalahan yang ada disekitar lingkungan peserta didik dengan kreatif. Potensi lokal Gunung Ijen dipilih sebagai tema dalam LKPD bertujuan untuk meningkatkan motivasi dan ketertarikan peserta didik terhadap pembelajaran IPA khususnya dalam bab lapisan bumi dan dinamikanya.

LKPD merupakan salah satu bahan ajar yang biasa dikembangkan untuk membantu pembelajaran di dalam kelas. Terdapat beberapa penelitan pengembangan yang telahh mengembangkan LKPD IPA seperti (Nurliawaty, Mujasam, Yusuf, \& Widyaningsih, 2017) mengembangkan LKPD berbasis problem solving (Firdaus \& Wilujeng, 2018) mengembangkan LKPD IPA berbasis inkuiri terbimbing, dan (Kartika, 2014) mengembangkan LKPD IPA berbasis metode Iqra'. LKPD IPA yang dikembangkan oleh peneliti memiliki perbedaan yaitu berbasis project-based learning ( $\mathrm{PjBL}$ ) yang dintegrasikan dengan potensi lokal Gunung Ijen. LKPD IPA hasil pengembangan dilengkapi 
dengan aspek-aspek yang mendukung untuk mengasah dan meningkatkan pemahaman konsep dan berpikir kreatif peserta didik seperti mencontohkan, merangkum, berdiskusi, mengklasifikasi, mengasah fleksibel, mengasah kelancaran, dan elaborasi. Setiap aspek pendukung disediakan kolom dalam LKPD yang berguna untuk membantu siswa dalam mendapatkan solusi kreatif dari permasalahan dan memahami konsep yang ada dalam LKPD.

Kelayakan produk LKPD diperoleh dari penilaian validator ahli materi, validator ahli media, dan praktisi guru IPA. Dalam tahap validasi diperoleh penilaian, kritik dan saran dari masing-masing validator. Hasil dari validasi kemudian dijadikan bahan untuk menyempurnakan produk LKPD IPA dalam tahap revisi. Revisi yang dilakukan terhadap produk LKPD IPA yang dikembangkan berdasarkan saran validator adalah mengganti ukuran font pada beberapa bagian LKPD yang kurang sesuai, mengganti pernyataan pada soal yang kurang sesuai dengan konsep agar tidak menimbulkan miskonsepsi pada peserta didik, mengganti permasalahan pada LKPD 1 karena dianggap kurang sesuai dengan konten, mengganti mini proyek satu dari poster menjadi mind map, memperbaiki ketentuan pelaksanaan proyek menjadi berurutan sesuai dengan sintak PjBL yang digunakan dalam LKPD IPA berbasis PjBL terintegrasi potensial lokal Gunung Ijen, dan melengkapi informasi dalam tahap penilaian proyek. Penailaian dari praktisi guru IPA juga memberikan saran untuk perbaikan LKPD IPA yaitu mencantumkan bahan bacaan yang dapat menjadi rujukan dalam mengerjakan LKPD, konsisten dalam menyebut LKPD atau LKS, memberi kepanjangan dari setiap singkatan.

Hasil penilaian kelayakan produk LKPD IPA oleh ahli materi dan ahli media menunjukkan bahwa LKPD IPA berbasis PjBL terintegrasi potensial lokal Gunung Ijen layak digunakan dengan kategori sangat baik. Kelayakan LKPD IPA oleh ahli materi dinilai dari beberapa aspek yaitu kelayakan isi, kebahasaan, penyajian, dan karakteristik. Kelayakan isi terdiri dari enam indikator yang meliputi kesesuaian materi dengan KI dan KD, cangkupan materi, kesesuaian dengan kebutuhan bahan ajar, kebenaran substansi materi pembelajaran, manfaat dalam penambahan wawasan peserta didik, dan kesesuaian dengan nilai moral dan sosial. Aspek kebahasaan yang diukur dalam LKPD IPA terdiri empat indikator yaitu keterbacaan, kejelasan informasi yang dimuat, kesesuaian dengan kai- dah Bahasa Indonesia yang baik dan benar, serta pemanfaatan bahasa secara efektif dan efisien. Aspek penyajian terdiri dari empat indikator yaitu kejelasan tujuan pembelajaran yang ingin dicapai, pemberian motivasi dan daya tarik, pemberian stimulus dan respon, dan kelengkapan informasi yang dimuat. Aspek terakhir adalah karakteristik dengan dua indikator yaitu menggunakan sintak $\mathrm{PjBL}$ dan pengintegrasian potensi lokal Gunung Ijen ke dalam produk. Setiap indikator terdiri dari 4 butir pernyataan. Penilaian kelayakan LKPD oleh ahli media berdasarkan dua aspek yaitu format LKPD dan kegrafikaan. Format LKPD terdiri dari tujuh indikator yaitu judul LKPD, petunjuk belajar, KI/KD, materi pembelajaran, informasi pendukung, tugas/langkah kerja, dan penilaian. Aspek kegrafikaan terdiri dari penggunaan jenis dan ukuran huruf, tata letak (lay out), ilustrasi dan gambar (foto), serta desain tampilan. Aspek format LKPD memperoleh skor sebesar 3,86 dan kegrafikaan memperoleh skor 3,5. Produk LKPD memperoleh skor akhir sebesar 3,68 dengan kategori sangat baik oleh validator ahli media. Skor yang diperoleh menunjukkan bahwa produk LKPD memenuhi indikator-indikator kelayakan yang harus dimiliki LKPD.

Hasil penilaian kelayakan LKPD IPA adalah sebagai berikut: kelayakan isi memperoleh skor sebesar 3.5, kebahasaan 4, penyajian 4, dan karakteristik sebesar 3,5. Berdasarkan hasil penilaian kelayakan LKPD IPA oleh ahli materi, diperoleh skor akhir sebesar 3,75 dengan kategori sangat baik. LKPD dapat dikatakan berkategori sangat baik karena hampir semua indikator penilaian kelayakan terpenuhi dengan baik.

Kelayakan produk juga dipertimbangkan dari segi kepraktisan LKPD yang dinilai oleh praktisi yaitu guru IPA. Perolehan skor kepraktisan yang diperoleh sebesar 3,84 dengan kategori sangat baik. Hasil keseluruhan dari penilaian kelayakan LKPD IPA berbasis PjBL terintegrasi potensial lokal Gunung Ijen menunjukkan bahwa produk LKPD ini praktis digunakan dalam pembelajaran IPA dalam materi lapisan Bumi dan dinamikanya. LKPD hasil pengembangan dapat dilihat pada link http://bit.ly/LKPDGunungIjen. LKPD IPA yang dikembangkan dapat dianggap layak untuk digunakan dalam pembelajaran IPA pada materi lapisan Bumi dan dinamikanya karena memenuhi hampir seluruh indikator yang harus dimiliki oleh LKPD sebagai bahan ajar sesuai dengan panduan yang dikeluarkan oleh (Departemen Pendidikan Nasional, 2008) yang berjudul Panduan Pengembangan Bahan Ajar. 
Pembelajaran dengan mengangkat potensi lokal merupkan pembelajaran yang mengangakat hal nyata di dekat peserta didik. Hal ini sesuai dengan yang diungkapkan oleh Juniati \& Sari (2016) bahwa potensi lokal merupakan pembelajaran nyata yang mampu melayani masyarakat dalam memecahkan masalah lingkungan. Pada penelitian kali ini, LKPD IPA berbasis PjBL terintegrasi potensial lokal Gunung Ijen memuat potensi lokal yang yang membantu peserta didik dalam memahami konsep tentang materi lapisan Bumi dan pengurangan resiko bencana. Materi tentang pengurangan resiko bencana akan membantu peserta didik dalam berpikir kreatif mengenai solusi yang bisa dilakukan untuk mengurangi dampak yang ditimbulkan akibat adanya gunung meletus dan gempa bumi.

Menurut Ojeda-Rosero, Cepeda-Ricaurte, \& López-Vázquez (2018) komunitas pendidikan merupakan bidang minat khusus yang berhubungan dengan resiko gunung berapi yang fokus pada banyak aspek kehidupan yang mewakili cara berpikir mereka. Suatu kelompok sekolah yang dilatih untuk merespon keadaan darurat dapat menjadi skenario dalam membangun nilai kolektif untuk memandu menemukan cara baru dalam mengetahui hubungan manusia dengan pencegahan bencana. Buku tersebut menjelaskan bahwa lingkungan sekolah merupakan komunitas yang sangat penting untuk dilatih dalam usaha pengurangan resiko bencana. Hal ini menguatkan bahwa LKPD IPA yang memuat pembelajaran tentang resiko pengurangan bencana sangat penting untuk dikembangkan.

Keefektifan produk diperoleh dari perbedaan rata-rata nilai postest pemahaman konsep dan berpikir kreatif dengan menggunakan soal uraian. Berdasarkan hasil uji MANOVA yang dilakukan terhadap nilai posttest, diperoleh hasil yang menunjukkan bahwa LKPD IPA berbasis PjBL terintegrasi potensial lokal Gunung Ijen berpengaruh secara signifikn terhadap pemahaman konsep dan berpikir kreatif peserta didik. Pengambilan keputusan kesimpulan bahwa $\mathrm{H}_{0}$ ditolak diperoleh dari nilai signfikansi uji MANOVA sebesar 0.000 yang lebih kecil dari alpha (sig < 0.05).

Hasil yang diperoleh dalam penelitian ini didukung oleh beberapa hasil penelitian yang relevan seperti penelitian yang dilakukan (Kusumaningrum \& Djukri, 2016) menghasilkan perangkat pembelajaran yang efektif digunakan untuk meningkatkan keterampilan proses sains dan kreativitas siswa khususnya pada aspek kemampuan berpikir kreatif kelas X SMAN 8
Yogyakarta. Penelitian (Mihardi, Harahap, \& Sani, 2010) menunjukkan bahwa kemampuan berpikir kreatif peserta didik dengan model project-based learning lebih tinggi daripada kemampuan berpikir kreatif dengan model kooperatif. Penelitian (Astuti, 2015) menunjukkan hasil yang sama yaitu pembelajaran di luar kelas berbasis proyek dapat meningkatkan keterampilan berpikir kreatif peserta didik dalam membuat proyek untuk menangani limbah yang ada di lingkungan sekolah. Dari beberapa penelitian tersebut menunjukkan bahwa PjBL dapat meningkatkan kreatiitas khususnya berpikir kreatif dalam pengurangan resiko bencana karena model pembelajaran $\mathrm{PjBL}$ melibatkan peserta didik dalam merancang, membuat, dan menampilkan produk untuk mengatasi masalah yang ada di dunia nyata (Sani, 2014).

Dalam penelitian yang dilakukan (Fuadah, Saptasari, \& Ibrohim, 2017) diperoleh hasil bahwa PjBL bersumber potensi lingkungan lokal dapat meningkatkan pemahaman konsep peserta didik. Hal ini ditunjukkan oleh $P$-value $<$ a $(0,05)$ dengan rerata terkoreksi kelas eksperimen yang lebih besar yaitu 67,513 sedangkan rerata terkoreksi kelas kontrol yaitu 52,96. Relevansi hasil penelitian (Fuadah, Saptasari, \& Ibrohim, 2017) dengan penelitian yang dikembangkan terdapat pada bagian model PjBL bersumber potensi lokal dapat meningkatkan pemahaman konsep peserta didik. Peningkatan pemahaman konsep peserta didik melalui model pembelajaran $\mathrm{PjBL}$ karena sintak yang dimiliki PjBL dapat membantu peserta didik dalam menafsirkan, mencontohkan, mengklasifikasi, dan menyimpulkan masalah yang sedang terjadi.

\section{SIMPULAN}

Berdasarkan hasil penelitian dan pengembangan yang telah dilakukan, dapat disimpulkan bahwa LKPD IPA berbasis PjBL terintegrasi potensi lokal Gunung Ijen layak digunakan sebagai bahan ajar dalam meningkatkan pemahaman konsep dan berpikir kreatif peserta didik dengan kategori sangat baik. LKPD IPA berbasis $\mathrm{PjBL}$ terintegrasi potensi lokal Gunung Ijen efektif secara signifikan dalam meningkatkan pemahaman konsep dan berpikir kreatif dalam pengurangan resiko bencana peserta didik. Pengetahuan tentang pengurangan resiko bencana sangat penting diajarkan kepada peserta didik sedini mungkin mengingat Indonesia merupakan negara rawan bencana. Kemampuan berpikir kreatif diperlukan peserta didik untuk menyelesaikan permasalahan dalam kehidupan 
nyata khususnya dalam usaha pengurangan resiko bencana.

\section{DAFTAR PUSTAKA}

Astuti, R. (2015). Meningkatkan kreativitas siswa dalam pengolahan limbah menjadi trash fashion melalui PjBL. Bioedukasi: Jurnal Pendidikan Biologi, 8(2), 37. https://doi.org/10.20961/bioedukasiuns.v8i2.3872

Badan Pusat Statistik. (2018). Proyeksi penduduk Indonesia, 2015-2045: Hasil SUPAS 2015. Jakarta: Badan Pusat Statistik. Retrieved from

https://www.bps.go.id/publication/2018/1 0/19/78d24d9020026ad95c6b5965/proyek si-penduduk-indonesia-2015-2045-hasilsupas-2015.html

Departemen Pendidikan Nasional. (2008). Panduan pengembangan bahan ajar. Jakarta: Depdiknas.

Firdaus, M., \& Wilujeng, I. (2018). Pengembangan LKPD inkuiri terbimbing untuk meningkatkan keterampilan berpikir kritis dan hasil belajar peserta didik. Jurnal Inovasi Pendidikan IPA, 4(1), 26-40. https://doi.org/10.21831/JIPI.V4I1.5574

Fuadah, K., Saptasari, M., \& Ibrohim, I. (2017). Project based learning bersumber belajar potensi lingkungan lokal terhadap pemahaman konsep, keterampilan ilmiah, dan sikap ilmiah siswa. Jurnal Pendidikan Biologi, 8(1), 10-16. https://doi.org/10.17977/JPB.V8I1.2272

Hake, R. R. (1999). Analyzing change/Gain scores. Retrieved from http://www.physics.indiana.edu/ sdi/Anal yzingChange-Gain.pdf

Juniati, E., \& Sari, W. P. (2016). Integrasi potensi lokal pada pembelajaran sl terhadap pembentukan learner softskill untuk memecahkan permasalahan lingkungan. In Prosiding Symbion (Symposium on Biology Education) (pp. 545-546). Yogyakarta: Universitas Ahmad Dahlan.

Kartika, I. (2014). Pengembangan lembar kerja peserta didik (LKPD) IPA terpadu berbasis model Iqra' dan mitigasi bencana erupsi Merapi. Al-Bidayah: Jurnal Pendidikan Dasar Islam, 6(1). https://doi.org/10.14421/albidayah.v6i1.138

Kementerian Pendidikan dan Kebudayaan
Republik Indonesia. (2013). Bahan sosialisasi Kurikulum 2013. Jakarta: Kementerian Pendidikan dan Kebudayaan.

Kusumaningrum, S., \& Djukri, D. (2016). Pengembangan perangkat pembelajaran model project based learning (PjBL) untuk meningkatkan keterampilan proses sains dan kreativitas. Jurnal Inovasi Pendidikan IPA, 2(2), 241. https://doi.org/10.21831/jipi.v2i2.5557

Mardapi, D. (2008). Teknik penyusunan instrumen tes dan nontes. Yogyakarta: Mitrs Cendikia Offset.

Mihardi, S., Harahap, M. B., \& Sani, R. A. (2010). The effect of project based learning model with KWL worksheet on student creative thinking process in physics problems. Journal of Education and Practice, 4(25), 188-200. Retrieved from

https://www.iiste.org/Journals/index.php/J $\mathrm{EP} /$ article/view/9086

Nurliawaty, L., Mujasam, M., Yusuf, I., \& Widyaningsih, S. W. (2017). Lembar kerja peserta didik (LKPD) berbasis problem solving Polya. JPI (Jurnal Pendidikan Indonesia), $\quad 6(1), \quad 72-81$. https://doi.org/10.23887/jpiundiksha.v6i1.9183

Ojeda-Rosero, D. E., Cepeda-Ricaurte, M., \& López-Vázquez, E. (2018). Adolescents' perceptions and behaviours regarding volcanic risk (pp. 193-207). Springer, Cham. https://doi.org/10.1007/978-3-31973799-7_13

Prastowo, A. (2011). Panduan kreatif membuat bahan ajar inovatif. Jogjakarta: DIVA Press.

Presiden Republik Indonesia. Undang-Undang Republik Indonesia nomor 20 tahun 2003 tentang sistem pendidikan nasional, Pub. L. No. 20, Undang-Undang Republik Indonesia 26 (2003). Indonesia.

Rosita, R. (2015). Edukasi bencana sejak dini. Retrieved September 2, 2019, from https://www.bnpb.go.id/edukasi-bencanasejak-dini

Sani, R. A. (2014). Pembelajaran saintifik untuk implementasi kurikulum 2013. Jakarta: Bumi Aksara.

Sudarma, M. (2013). Mengembangkan keterampilan berpikir kreatif. Jakarta: 


\section{Jurnal Inovasi Pendidikan IPA, 5 (1), 2019 - 128}

Khatriya Tiffani Tamimiya, I Gusti Putu Suryadarma

Raja Grafindo Persada.

Sya `ban, M. F., \& Wilujeng, I. (2016). Pengembangan SSP zat dan energi berbasis keunggulan lokal untuk meningkatkan literasi sains dan kepedulian lingkungan. Jurnal Inovasi Pendidikan IPA, 2(1), 66 . https://doi.org/10.21831/jipi.v2i1.8369

Wakil Menteri Bidang Pendidikan dan Kebudayaan Republik Indonesia. (2004). Konsep dan implementasi Kurikulum 2013. Jakarta: Kementerian Pendidikan dan Kebudayaan.

Wiek, A., Xiong, A., Brundiers, K., \& van der
Leeuw, S. (2014). Integrating problemand project-based learning into sustainability programs. International Journal of Sustainability in Higher Education, 15(4), 431-449. https://doi.org/10.1108/IJSHE-02-20130013

Wilujeng, I., Prasetyo, Z. K., \& Suryadarma, I. G. P. (2017). Science learning based on local potential: Overview of the nature of science (NoS) achieved. In AIP Conference Proceedings (Vol. 1868, p. 080005). AIP Publishing LLC. https://doi.org/10.1063/1.4995189 